\title{
AGRONOMIC PERFORMANCE AND ADAPTABILITY OF THREE VARIETIES OF WATERMELON (Citrullus lanatus) ON SANDY LOAM SOIL IN DERIVED SAVANNA
}

\author{
Oraegbunam $^{1}$, C.J., Njoku ${ }^{2}$, O.M., Imoh ${ }^{1}$, O.N., Obalum ${ }^{2 *}$, S.E., \\ Onyia $^{1}$, V.N., Atugwu ${ }^{1}$, A.I., and Uchida ${ }^{3}$, Y. \\ ${ }^{1}$ Department of Crop Science, University of Nigeria, Nsukka 410001, Nigeria \\ ${ }^{2}$ Department of Soil Science, University of Nigeria, Nsukka 410001, Nigeria \\ ${ }^{3}$ Faculty of Agriculture, Hokkaido University, Japan \\ *Corresponding author's email: sunday.obalum@unn.edu.ng
}

\begin{abstract}
Amidst tropical vegetables, watermelon (Citrullus lanatus) is increasing popular for its numerous health benefits. In Nigeria, this vegetable crop is still under-produced in the relatively more humid southern part where it is heavily consumed. This situation is partly due to lack of empirical data on existing exotic and local varieties particularly in the southeastern region of the country. In this study, field trials with three watermelon varieties [Lagone (exotic), Koloss (exotic) and Charleston gray (local) serving as control] were conducted on a sandy loam acid soil at Nsukka in southeastern Nigeria typifying Derived Savanna. They were evaluated for agronomic performance including vegetative growth and fruit yield. Koloss took less time ( 10 days) to emerge compared to Lagone (15 days) and Charleston gray (14 days). Lagone attained first and 50\% flowering earlier (36 and 39 days, respectively) than the others. Charleston gray had the longest vine $(196.42 \mathrm{~cm})$ nine weeks after planting but showed fewer fruits $(3.33)$ than the others, while Koloss showed largest fruit width $(15.66 \mathrm{~cm})$. Fresh fruit yield indicated nominal differences but tended to be highest in Koloss $(1.95 \mathrm{~kg} / \mathrm{plant})$; Lagone and Charleston gray had 1.85 and $1.74 \mathrm{~kg} / \mathrm{plant}$, respectively. For enhanced production of watermelon, Koloss is recommended to farmers in Nsukka agro-environment and similar climate-soil zones in the savanna. In the future, this exotic variety could be hybridized with the local Charleston gray and the hybrid seeds evaluated against the pure lines.
\end{abstract}

Key words: watermelon ecology, exotic varieties, vegetative growth, fruit yield

\section{INTRODUCTION}

Among the tropical vegetables, watermelon (Citrullus lanatus) is increasingly popular as a source of low-calorie food whose fruit and vegetative parts are highly nutritious and medicinal. It is a warm season annuals and so is well adapted to areas where high temperatures prevail for long periods in the year (Uguru, 1996). As a warm season crop, it is less tolerant to low temperature than other cucurbits such as cucumber (Cucumis sativus) and cantaloupe (Cucumis melo). Watermelon has a long prostrate vine growth and so requires ample spacing on well-drained soils that are rich in organic matter and with good water retention capacity (Lawal, 2000).

Watermelon has a smooth skin and the flesh is juicy and crunchy. The seeds are usually black and embedded in the fruit. It is a traditional food plant in Africa with potential to improve nutrition, boost food security, foster rural development and support sustainable land use (Wang et al., 2004). The fruits are often fermented, blended and consumed as juice, nectars and fruit cocktails. Sometimes, the finished product can also serve as appetizers, depending on such factors as mode of preparation (Onyeleke and Olaniyan, 2007; Oms-Oliu et al., 2009; Enukainure et al., 2010).

In Nigeria, watermelon is produced largely in the drier core savanna zones (Schippers, 2000), bulk of which are in the North. Its production across agro-environments in the South is still low vis-a-vis the high rate of its consumption there. This situation in the South is due partly to high humidity that is known to adversely affects flowering, and to inappropriate soil and water management practices. Another major challenge particularly in the southeastern part is insufficiency of data on adaptability and relative performance of varieties across agro-environments.

There are over 100 varieties of watermelon ranging in weight from less than $1.40 \mathrm{~kg}$ to more than $32 \mathrm{~kg}$. Some are round and others oblong in shape. The varieties also vary in skin colour from light green to dark green while some have stripes. 
The colour of the flesh may be red, orange, yellow or white. For a meaningful crop improvement, there must be sufficient genetic resources whose potentials for crop improvement are known. Genetic resources are useful to plant breeders only after they have been characterized and evaluated ( $\mathrm{Ng}$ and $\mathrm{Ng}, 1991)$. Such studies enable plant scientists to understand the diversity of a species to guide the search for ideal cultivars, or to provide genetic variability in a breeding program.

Some exotic varieties, including one also involved in the present study, have been evaluated in southeastern Nigeria (Anikwe et al., 2016). The challenge regarding data on relative performance of varieties is, however, not yet fully tackled in the derived savanna of the region. Specifically, there is still paucity of literature on the growth and yield performances of different exotic and local tropical watermelon varieties in Nsukka area that typifies the derived savanna of southeastern Nigeria. This has led to the initiation of the present research on a sandy loam soil at the university town of Nsukka. The objectives were: (i) to evaluate the variety for vegetative growth and fruit yield performance, and (ii) to study their adaptability in the ecological zone.

\section{MATERIALS AND METHODS} Experimental Site

The experiment was carried out at the Teaching and Research Farm of the Faculty of Agriculture, University of Nigeria, Nsukka $\left(06^{\circ} 86^{\prime} \mathrm{N}, 07^{\circ} 42^{\prime} \mathrm{E}\right)$, on mean elevation of about $400 \mathrm{~m}$ above sea level. Nsukka has a tropical humid climate with distinct rainy season (April - October) and dry season (November - March). Mean annual total rainfall is $1600 \mathrm{~mm}$ which is often less than the mean annual evapotranspiration in recent years. Mean minimum and maximum annual temperatures are 21 and $31^{\circ} \mathrm{C}$, respectively, with sometimes supra-optimal values of up to $35^{\circ} \mathrm{C}$. Relative humidity is within the range of $55-80 \%$ throughout the year.

Nsukka is in the Derived Savanna of Southeastern Nigeria. The soil is deeply weathered, reddish brown sandy loam classified as Acrisols. It has mean topsoil silt and clay contents of 80 and $160 \mathrm{~g} \mathrm{~kg}^{-1}$, respectively and is therefore very porous, well-drained and drought-prone. Also, as shown elsewhere (Obalum et al., 2011), the soil is known to be acidic ( $\mathrm{pH}$ of 5.4) and low inorganic matter $\left(11.38 \mathrm{~g} \mathrm{~kg}^{-1}\right)$ and, hence, of low fertility; total nitrogen of $0.70 \mathrm{~g} \mathrm{~kg}^{-1}$, available phosphorus of $29.80 \mathrm{mg} \mathrm{kg}$, and apparent cation exchange capacity of $6.30 \mathrm{cmol} \mathrm{kg}^{-1}$.

\section{Field Establishment}

The field study was started at the onset of 2014 rainy season and it lasted three months. The watermelon varieties studied were three accessions; one local variety, Charleston gray, and two exotic varieties, Lagone and Koloss (Figure 1). The experimental field, $17 \mathrm{~m} \times 17 \mathrm{~m}$, was cleared manually and ploughed/harrowed with tractor. Considered as treatments, the accessions/varieties were replicated five times in a randomized complete block design (RCBD). Treatment plots (each, $5 \mathrm{~m} \times 3 \mathrm{~m}$ ) were $1 \mathrm{~m}$ apart and blocks/replicates $0.5 \mathrm{~m}$ apart. Two seeds were sown per hill at plant spacing of $1 \mathrm{~m} \times 1 \mathrm{~m}$, giving 15 potential stands per plot.

\section{Crop Husbandry and Data Collection}

Weeding was done at three-week intervals till maturity and harvest. Inorganic fertilizer (NPK 15:15:15) was applied at the rate of $150 \mathrm{~kg} \mathrm{ha}^{-1}$ three weeks after planting (WAP). Liquid forms of plant protectants including Metazeb 72WP, Termex and Diutryn 11EC were applied to control pest infestation and disease infection at 6 WAP.

In each plot, data were collected on four randomly selected plants. Parameters measured included days to emergence, days to first and 50\% flowering, vine length $(\mathrm{cm})$, number of nodes and internodes, and number of branches at three-week intervals. Also, fresh fruits were harvested at senescing (i.e., when the leaves began to dry up and the stalk turned brown) and number of fruits (fruit count), fruit length $(\mathrm{cm})$, fruit width $(\mathrm{cm})$ and fruit weight $(\mathrm{kg})$ were assessed.
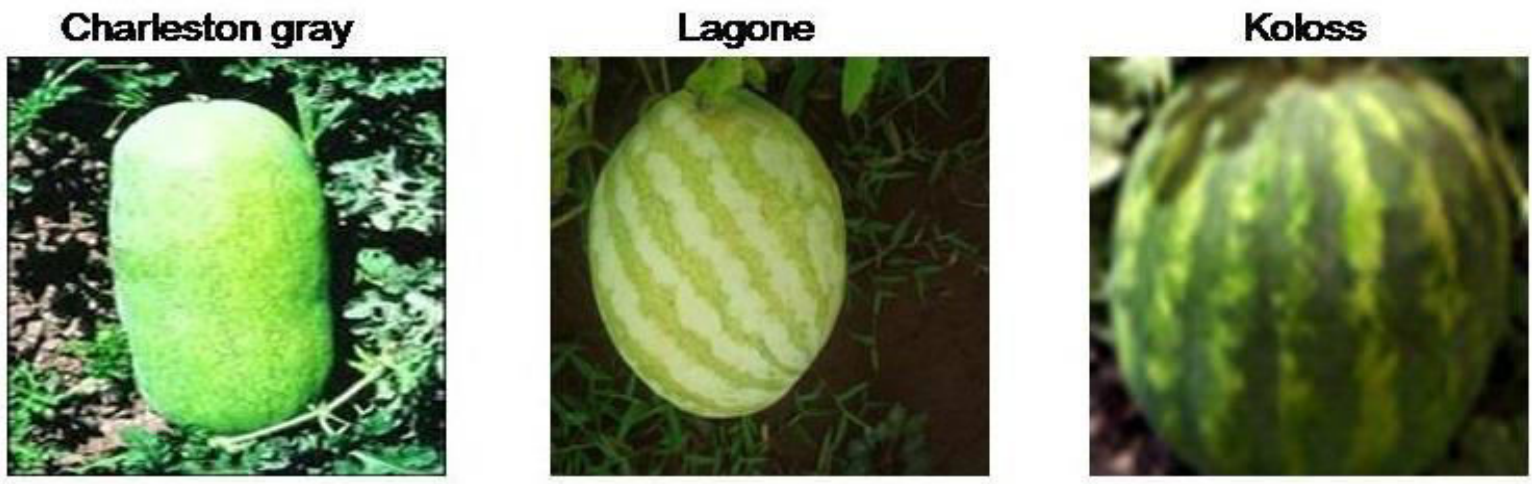

Figure 1: Mature fruits of the three watermelon varieties of the study 


\section{Statistical Analysis}

Data were subjected to analysis of variance procedures for experiments in RCBD as shown in Table 1. Means were separated by the method of least significant difference (LSD) with differences deemed significant at $5 \%$ probability level.

\section{RESULTS}

Days to Emergence and Flowering

The number of days to emergence and flowering of the watermelon variety are shown (Table 2). There were significant differences in these two parameters among them. Koloss had lower values for days to emergence than Charleston gray and Lagone, whereas Lagone recorded lower values for days to first flowering and $50 \%$ flowering compared to the other two varieties.

\section{Vine Length and Number of Branches}

Vine length of the three watermelon varieties during 3-12 WAP are shown (Table 3). Vine length indicated similar values among the varieties at 3 and 6 WAP; however, Lagone showed shorter vines than Charleston gray at 9 WAP and than both Koloss and Charleston gray at 12 WAP. The number of branches during 6-12 WAP is shown in Table 4. There were no significant differences among the three varieties at 6 WAP. However, Charleston gray had more branches at 9 and 12 WAP compared to Lagone and Koloss both for which values were similar.

\section{Number of Nodes and Internodes}

The number of nodes and internodes at 6, 9 and 12 WAP is shown in Table 5. There were no significant differences in these two related agronomic parameters at 6 WAP. However, their values were higher in Charleston gray compared with Koloss and Lagone at 6 WAP. This effect later became pronounced; at 9 and 12 WAP Charleston gray showed higher values for both parameters than Koloss which in turn showed generally higher values than Lagone.

\section{Fruit Count, Fruit Length/Width and Weight}

The data for the number of fruits (fruit count) and fruit length, width and weight are shown (Table 6). Lagone and Koloss had more fruits compared with Charleston gray. Values for fruit width were higher for Koloss than for Lagone and Charleston gray. However, fruit length and fruit weight of the three varieties indicated similar values.
Table 1: Analysis of variance table used for the experiment $(r=5, t=3)$

\begin{tabular}{lcc}
\hline $\begin{array}{l}\text { Source of } \\
\text { variation }\end{array}$ & $\begin{array}{c}\text { Degree of freedom } \\
\text { (General) }\end{array}$ & $\begin{array}{c}\text { Degree of freedom } \\
\text { (Specific) }\end{array}$ \\
\hline Block & $\mathrm{r}-1$ & 4 \\
Treatment & $\mathrm{t}-1$ & 2 \\
Error & $(\mathrm{r}-1)(\mathrm{t}-1)$ & 8 \\
Total & $\mathrm{tr}-1$ & 14 \\
\hline
\end{tabular}

Table 2: Number of days to emergence, first and $50 \%$ flowering of the watermelon varieties

\begin{tabular}{lccc}
\hline Variety & $\begin{array}{c}\text { Days to } \\
\text { emergence }\end{array}$ & $\begin{array}{c}\text { Days to first } \\
\text { flowering }\end{array}$ & $\begin{array}{c}\text { Days to 50\% } \\
\text { flowering }\end{array}$ \\
\hline $\begin{array}{l}\text { Charleston } \\
\text { gray }\end{array}$ & 14.00 & 37.33 & 41.67 \\
Lagone & 15.00 & 36.33 & 38.69 \\
Koloss & 9.67 & 37.00 & 41.67 \\
LSD $_{(0.05)}$ & $1.02 *$ & $0.61 *$ & $1.56 *$ \\
\hline Significantly different at $P<0.05$ & &
\end{tabular}

Table 3: Mean values of vine length $(\mathrm{cm})$ of the three varieties at 3, 6,9 and 12 weeks after planting

\begin{tabular}{lcccc}
\hline \multirow{2}{*}{ Variety } & \multicolumn{4}{c}{ Weeks after planting } \\
\cline { 2 - 5 } & 3 & 6 & 9 & 12 \\
\hline Charleston gray & 4.68 & 86.75 & 196.42 & 265.33 \\
Lagone & 4.15 & 84.83 & 163.08 & 220.17 \\
Koloss & 3.97 & 75.67 & 189.33 & 275.83 \\
LSD $_{(0.05)}$ & $1.03^{\mathrm{ns}}$ & $20.21^{\mathrm{ns}}$ & $29.48^{*}$ & $34.32^{*}$ \\
\hline
\end{tabular}

*Significantly, ${ }^{\text {ns }}$ Not significantly different at $P<0.05$

Table 4: Mean values for number of branches of the watermelon varieties at 6,9 and 12 weeks after planting

\begin{tabular}{lccc}
\hline \multirow{2}{*}{ Variety } & \multicolumn{3}{c}{ Weeks after planting } \\
\cline { 2 - 4 } & 6 & 9 & 12 \\
\hline Charleston gray & 3.42 & 13.67 & 15.00 \\
Lagone & 2.92 & 7.83 & 8.67 \\
Koloss & 2.50 & 7.33 & 9.00 \\
LSD $_{(0.05)}$ & $1.43^{\text {ns }}$ & $3.20 *$ & $2.96^{*}$ \\
\hline$*$ Significantly, ${ }^{\text {ns Not significantly different at } P<0.05}$
\end{tabular}

*Significantly, ${ }^{\text {ns }}$ Not significantly different at $P<0.05$

Table 5: Mean values for number of nodes/internodes of the watermelon varieties at 6, 9 and 12 weeks after planting

\begin{tabular}{|c|c|c|c|c|c|c|}
\hline \multirow{2}{*}{ Variety } & \multicolumn{3}{|c|}{ Number of nodes } & \multicolumn{3}{|c|}{ Number of internodes } \\
\hline & 6 & 9 & 12 & 6 & 9 & 12 \\
\hline Charleston gray & 37.83 & 179.08 & 227.92 & 36.83 & 178.08 & 226.92 \\
\hline Lagone & 32.83 & 128.42 & 173.08 & 31.83 & 127.50 & 172.08 \\
\hline Koloss & 31.33 & 144.17 & 195.42 & 30.33 & 143.17 & 172.08 \\
\hline $\operatorname{LSD}_{(0.05)}$ & $11.08^{\mathrm{ns}}$ & $19.65^{*}$ & $12.48^{*}$ & $11.08^{\mathrm{ns}}$ & $19.63 *$ & $12.4^{*}$ \\
\hline
\end{tabular}

*Significantly, ${ }^{\text {ns }}$ Not significantly different at $P<0.05$ 
Table 6: Mean values for number of fruits per plant, fruit length, fruit width and fruit weight of the watermelon varieties

\begin{tabular}{lcccc}
\hline Variety & $\begin{array}{c}\text { Number } \\
\text { of fruits } \\
\text { per plant }\end{array}$ & $\begin{array}{c}\text { Fruit } \\
\text { length } \\
(\mathrm{cm})\end{array}$ & $\begin{array}{c}\text { Fruit } \\
\text { width } \\
(\mathrm{cm})\end{array}$ & $\begin{array}{c}\text { Fruit weight } \\
\text { per plant } \\
(\mathrm{kg})\end{array}$ \\
\hline $\begin{array}{l}\text { Charleston } \\
\text { gray }\end{array}$ & 3.33 & 14.72 & 13.70 & 1.74 \\
Lagone & 4.33 & 13.61 & 14.25 & 1.85 \\
Koloss & 4.33 & 13.94 & 15.66 & 1.95 \\
$\operatorname{LSD}_{(0.05)}$ & $0.66^{*}$ & $1.29^{\mathrm{ns}}$ & $0.87^{*}$ & $0.35^{\mathrm{ns}}$ \\
\hline
\end{tabular}

*Significantly, ${ }^{\mathbf{n s}}$ Not significantly different at $P<0.05$

\section{DISCUSSION}

The results attained in this study show that the three watermelon varieties differed in some of the agronomic traits evaluated. The shortest interval to seedling emergence was recorded for Koloss. Sowing was done early in the rainy season. Low humidity probably favours seedling emergence in Koloss. Lagone had delayed seedling emergence but flowered relatively early, suggesting that emergence and flowering are controlled by different genes. Charleston gray and Koloss probably suffered greater drought-induced reduction in total dry matter and the associated delay in flowering often reported for watermelon (Lu et al., 2003; Ufoegbune et al., 2014).

Vine length showed no definite pattern but was shorter for Lagone than for the other two varieties at maturity. Koloss had the longest vines and was, expectedly, the most productive, for vine length affects the number of staminate and pistillate flowers in a watermelon plant (Dittmar et al., 2009). Differences in number of nodes and internodes as from 9 WAP agree with the study by Dittmar et al. (2009) on loamy sand at North Carolina. Charleston gray and Lagone had the highest and lowest numbers of nodes/internodes, respectively. Watermelon develops flowers on nodes; hence many internodes imply optimal productivity (Robinson and Decker-Walters, 1997; Rubatzky and Yamaguchi, 1997).

However, the occurrence of more internodes in Charleston gray did not result in higher number of fruits and fruit yield. The genetic potential of this variety may be harnessed through hybridization with another variety with desired traits. Koloss is a good candidate, based on the observations in this study. Ogbu et al. (2016) reported this variety as good for use in intergeneric hybridization to improve egusi melon (Colocynthis citrillus L.).

Higher number of branches per plant in Charleston gray implies that this local variety has good genetic make-up and resources that found the study environment favourable to express into rapid growth and branching (Akinfosoye et al., 1997; Ray and Sinclair, 1997). Charleston gray had fewest fruits that tended to be the longest. Koloss had the largest fruit width and tended to show the highest fruit weight. This observation in Koloss seems to suggest better genetic resource (Clark et al., 1997), as well as high stomata conductance and better partitioning of photosynthates for economic yield (Gardner et al., 1990; Zaki et al., 1999).

Lack of genetic variations and slow improvement in fruit yield is common in watermelon breeding (Gusmini and Wehner, 2005). Our data show that watermelon varieties studied differed in all the traits except in yield. Yield differences among watermelon varieties seem to be environment-specific (Anikwe et al., 2016). It could be that the varieties of the present study lacked the diversity needed to cause differences in fruit yield (Gusmini and Wehner, 2005), and/or that the environmental factors at Nsukka do not permit such expression of differences in yield.

By the plant spacing of $1 \mathrm{~m} \times 1 \mathrm{~m}$ used in this study, the mean fresh fruit yield of the three varieties when expressed on hectarage basis translates into 17.40-19.50 $\mathrm{t} \mathrm{ha}^{-1}$. This yield is encouraging when related to the yields reported from some other locations in the Derived Savanna of southeastern Nigeria. These include 12.45-13.44 $\mathrm{t}$ ha $^{-1}$ under much closer spacing and heavier fertilization (Awere and Onyeacholem, 2014), and 7.98-13.04 and 0.00-1.75 $\mathrm{t} \mathrm{ha}^{-1}$ reported of five varieties including Koloss under similar plant spacing and fertilization (Anikwe et al., 2016). Perhaps, the climate and soils of Nsukka offer greater prospects for the production of watermelon that is known to abhor excessive humidity.

Without prejudice to the above inference, the soil of this study is well-drained and often droughty, with available water capacity often as low as $20 \mathrm{~cm} \mathrm{~m}^{-1}$ (Obalum and Obi, 2013). Thus the soil does not always fully satisfy the edaphological requirement for watermelon (Lawal, 2000), and this calls for such drought management strategies for the crop as supplemental irrigation and mulching (Lu et al., 2003, Wakindiki and Kirambia, 2011). Since the present field trial was solely rainfed and without mulching, the crop's performance and hence success of all the crosses done might have been adversely affected.

\section{CONCLUSIONS}

For enhanced growth and yield of watermelon on sandy loam soils in Nsukka area and edaphologically similar agro-environments in the Derived Savanna, farmers should plant the exotic variety, Koloss. In view of the dissimilarity between Koloss and Charleston gray (the local variety) in most of the parameters evaluated, the duo could potentially be excellent hybridizers. In the future, hybrid seeds emanating from them should be evaluated to determine if they could serve as good planting resource materials for the farmers. 


\section{REFERENCES}

Akinfosoye, J.A., Olafolaji, A.O., Tairu, F.M., and Adenowola, R.A. (1997). Effect of different phosphorus levels on the yield of four variety of rained tomato (Lycopersicom esculentum). Proceedings, 15th HORTSON Conference, 1, 65-66

Anikwe, M.A.N., Agu, J.C., and Ikenganyia, E.E. (2016). Agronomic evaluation of four exotic tropical variety of watermelon (Citrullus lanatus L.) in two agroenvironments in Nigeria. International Journal of Plant and Soil Science, 10, 1-10

Awere, S.U. and Onyeacholem, D.A. (2014). Effect of spacing and NPK 20:10:10 fertilizer on the growth and yield of watermelon (Citrullus lanatus) in Enugu, South Eastern Nigeria. Journal of Experimental Research, 2, 93-99

Clark, R.B., Zeto, S.K., Baligar, V.C., and Ritchey, K.D. (1997). Growth traits and mineral concentrations of maize hybrids grown on unlimed and limed acid soil. Journal of Plant Nutrition, 20, 1773-1795

Dittmar, P.J., Monks, D.W., and Schultheis, J.R. (2009). Maximum potential vegetative and floral production and fruit characteristics of watermelon pollenizers. HortScience, 44, 59-63

Enukainure, O.L., Oke, O.V., Daramola, A.O., Adenekan, S.O., and Umanhonlem, E.E. (2010). Improvement of biochemical properties of watermelon rinds subjected to $S$. cerevisiae solid media fermentation. Pakistan Journal of Nutrition, 9, 806-809

Feyzian, E., Dehghani, H., Rezai, A.M., and Jalali Javaran, M. (2009). Diallel cross analysis for maturity and yield-related traits in melon (Cucumis melo L.). Euphytica, 168, 215-223

Gardner, F.P., Alle, V., and McCloud, D.E. (1990). Yield characteristics of ancient roses of maize compared to modern hybrid. Agronomy Journal, 82, 864-868

Gusmini, G. and Wehner, T.C. (2005). Foundations of yield improvement in watermelon. Crop Science, $45,141-146$

Lawal, A.B. (2000). Response of cucumber to intercropping with maize and varying rates of farmyard manure and inorganic fertilizer. Agriculture and Environment, 2, 78-83

Lu, W., Edelson, J.V., Duthie, J.A., and Roberts, B.W. (2003). A comparison of yield between high- and low-intensity management for three watermelon cultivars. HortScience, 38, 351-356

Milic, D., Katic, S., Mihailovic, V., Mikic, A., Karagic, D., and Vasiljevic, S. (2010). Diallel analyses of the inheritance of dry matter quality traits in alfalfa (Medicago sativa L.). Proc. XII Int. Symp. on Forage Crops of Republic of Serbia: Forage Crops Basis of the Sustainable Animal Husbandry Development. Biotechnology in Animal Husbandry (spec. issue), 26, 7-15

$\mathrm{Ng}$, S. and Ng, N. (1991). Reduced-growth storage of germplasm. In: In Vitro Methods for Conservation of Plant Genetic Resources. (eds. Dodds J.), pp. 1139. London, Chapman and Hall
Obalum, S.E. and Obi, M.E. (2013). Moisture characteristics and their point pedotransfer functions for coarse-textured tropical soils differing in structural degradation status. Hydrological Processess, 27, 2721-2735

Obalum, S.E., Okpara, I.M., Obi, M.E., and Wakatsuki, T. (2011). Short-term effects of tillage-mulch practices under sorghum and soybean on organic carbon and eutrophic status of a degraded Ultisol in southeastern Nigeria. Tropical and Subtropical Agroecosystems, 14, 393-403

Ogbu, V.O., Ogbonna, P.E., Onyia, V.N., and Okechukwu, E.C. (2016). Yield improvement of egusi melon (Colocynthiscitrillus L.) through intergeneric hybridization with watermelon (Citrillus lanatus L.). The Journal of Animal and Plant Sciences, 26, 1291-1297

Oms-Oliu, G., Odriozola-Serrano, I., Soliva-Fortuny, R., and Martín-Belloso, O. (2009). Effects of highintensity pulsed electric field processing conditions on lycopene, vitamin $\mathrm{C}$ and antioxidant capacity of watermelon juice. Food Chemistry, 115, 1312-1319

Onyeleke, F.I. and Olaniyan, A.M. (2007).Extraction of juice from some tropical fruits using a small scale multi fruit juice extractor. African Crop Science Proceedings, 8, 1803-1808

Robinson, R.W. and Decker-Walters, D.S. (1997). Cucurbits. Wallingford, UK, CAB Int. Publishing.

Rubatzky, V.E.,and Yamaguchi, M. (1997). World Vegetables; Principles, Production and Nutritive Values, 2nd ed. New York, Chapman \& Hall Publ

Schippers, R.R. (2000). African Indigenous Vegetables: An Overview of the Cultivated Species. University of Greenwich, Natural Resources Institute, London, UK, $214 \mathrm{pp}$

Ufoegbune, G.C., Fadipe, O.A., Belloo, N.J., Eruola, A.O., Makinde, A.A., and Amori, A.A. (2014). Growth and development of watermelon in response to seasonal variation of rainfall. Journal of Climatology and Weather Forecasting, 2, 117. doi:10.4172/2332-2594.1000117

Uguru, M.I. (1996). Crop Production: Tools, Techniques and Practice. Nsukka: Fulladu Publishing Company

Wakindiki, I.I.C. and Kirambia, R.K. (2011). Supplemental irrigation effects on yield of two watermelon (Citrulus lanatus) cultivars under semiarid climate in Kenya. African Journal of Agricultural Research, 6, 4862-4870

Wang, Y., Xie, Z.K., Lim, F., and Zhang, Z. (2004). The effect of supplemental irrigation on watermelon (Citrullus lanatus) production in gravel and sand mulched fields in the Loess Plateau of northwest China. Agricultural Water Management, 69 (1), 29-41

Zaki, N.M., El-Gazar, M.M., El-Din, K.M.G., and Ahmed, M.A. (1999). Partition and migration of photosynthates in some maize hybrids. Egyptian Journal of Applied Science, 14, 117-139 